\title{
Assessment of chemical and mineralogical characteristics of airborne dust in the Sistan region, Iran
}

\author{
A. Rashki ${ }^{1,2}$, P.G. Eriksson ${ }^{3}$, C.J.deW. Rautenbach ${ }^{1}$, D.G. Kaskaoutis ${ }^{4}$, W.Grote ${ }^{3}$ and J. \\ Dykstra $^{3}$ \\ ${ }^{1}$ Department of Geography, Geoinformatics and Meteorology, Faculty of Natural and Agricultural Sciences, \\ University of Pretoria, Pretoria 0002, South Africa \\ ${ }^{2}$ Department of Drylands and Desert Management, Faculty of Natural Resources and Environment, Ferdowsi \\ University of Mashhad, Mashhad, Iran \\ ${ }^{3}$ Department of Geology, Faculty of Natural and Agricultural Sciences, University of Pretoria, Pretoria 0002, \\ South Africa \\ ${ }^{4}$ Research and Technology Development Centre, Sharda University, Greater Noida - 201306, India
}

Principal Contact: Alireza Rashki, Tel.: +27-(0)729090950, Fax: +27-(0)12-420 2489,

E-mail: Alireza.Rashki@up.ac.za

\begin{abstract}
Windblown transport and deposition of dust is widely recognized as an important physical and chemical concern to climate, human health and ecosystems. Sistan is a region located in southeast Iran with extensive wind erosion, severe desertification and intense dust storms, which cause adverse effects in regional air quality and human health. To mitigate the impact of these phenomena, it is vital to ascertain the physical and chemical characteristics of airborne and soil dust. This paper examines for the first time, the mineralogical and chemical properties of dust over Sistan by collecting aerosol samples at two stations established close to a dry-bed lake dust source region, from August 2009 to August 2010. Furthermore, soil samples were collected from topsoil $(0-5 \mathrm{~cm}$ depth) at several locations in the dry-bed Hamoun lakes and downwind areas. These data were analyzed to investigate the chemical and mineralogical characteristics of dust, relevance of inferred sources and contributions to air pollution. X-Ray Diffraction (XRD) analysis of airborne and soil dust samples shows that the dust mineralogy is dominated mainly by quartz (30-40\%), calcite (18-23\%), muscovite $(10-17 \%)$, plagioclase $(9-12 \%)$, chlorite $(\sim 6 \%)$ and enstatite $(\sim 3 \%)$, with minor components of dolomite, microcline, halite and gypsum. X-Ray Fluorescence (XRF) analyses of all the samples indicate that the most important oxide compositions of the airborne and soil dust are $\mathrm{SiO}_{2}, \mathrm{CaO}, \mathrm{Al}_{2} \mathrm{O}_{3}, \mathrm{Na}_{2} \mathrm{O}, \mathrm{MgO}$ and $\mathrm{Fe}_{2} \mathrm{O}_{3}$, exhibiting similar percentages for both stations and soil samples. Estimates of Enrichment Factors (EF) for all studied elements show that all of them have very low EF values, suggesting natural origin from local materials. The results suggest that a common dust source region can be inferred, which is the eroded sedimentary environment in the extensive Hamoun dry lakes lying to the north of Sistan.
\end{abstract}

Keywords: Aeolian dust, dust chemistry, mineralogical composition, Hamoun lakes, Sistan, Iran. 


\section{Introduction}

Mineral dust plays an important role in the optical, physical and chemical processes in the atmosphere (Xi and Sokolik, 2012), while dust deposition adds exogenous mineral and organic material to terrestrial surfaces, having a significant impact on the Earth's ecosystems and biogeochemical cycles (Jickels et al., 2005; Lawrence and Neff, 2009). Dust particles are fine airborne soil and/or weathered or transported rock particles removed from the Earth's surface as a result of wind erosion under certain climatic, meteorological and soil conditions. The Earth's surface is composed of a large number of minerals, which occur in heterogeneous mixtures within rocks and weathering mantles. Analysis of the physical properties and chemical composition of dust aerosols is, therefore, important to determine aerosol sources, mixing processes and transport pathways (Bergametti et al., 1989; McConnell et al., 2008; Mishra and Tripathi, 2008). It is estimated that 1000-3000 Tg of mineral aerosols are emitted annually into the atmosphere over the globe (d'Almeida, 1987; Jones et al., 1995), which can be transported over long distances (e.g., Prospero, 1999). The role of dust aerosols in atmospheric processes, i.e. Earth's radiation balance, cloud microphysics, etc, strongly depends on a variety of physico-chemical parameters, size distribution, dust sources, atmospheric lifetime and mixing processes in the atmosphere (Charlson et al., 1992; Tegen and Fung, 1994; Andreae, 1996; Frank et al., 1996; Sokolik et al., 1998; Rosenfeld et al., 2008).

Some dust contaminants (soluble and chelatable metallic salts, pesticides, etc) affect human health when they are transported over densely populated areas (Larney et al., 1999), retained in residences and other occupied structures (Lioy et al., 2002), and they also impact the nutrient loading of waters flowing from adjacent watersheds (Wood and Sanford, 1995) and terminal bodies of water by direct and indirect deposition (Ganor et al., 2003; Lawrence and Neff, 2009). Particulate Matter (PM) is a complex mixture of substances suspended into the atmosphere in solid or liquid state with different properties (e.g., variable size distribution or chemical composition amongst others) and origins (anthropogenic and natural). Owing to this mixture of substances, the chemical composition of PM may vary widely as a function of emission sources and the subsequent chemical reactions which take place in the atmosphere 
(Chow et al., 2003; Engelbrecht et al., 2009; Mishra et al., 2008). Therefore, it is important to determine temporal variations in aerosol concentrations to assess health exposure effects and to improve correlations between source emission rates and ground-based measurements (Christopher et al., 2004; Kidwell and Ondov, 2001; Nastos et al., 2010). The chemical mass balance is the most commonly used method for assessing PM source contributions (Wilson et al., 2002), while statistical methods, such as factor analysis and multi-linear regression (Thurston and Spengler, 1985), have also produced interesting results regarding dust source identification. Elemental and mineralogical analyses have also been used to identify the source regions of dust deposited in Arctic ice caps (Biscaye and Grousset, 1998) and on other depositional surfaces (Shaw, 1980; Lawrence and Neff, 2009).

The Sistan region located in southeastern Iran is a major dust source in southwest Asia (Goudie and Middleton, 2000), often producing intense dust storms that cover Sistan, and the southwest of Afghanistan and Pakistan (Alam et al., 2011; Rashki et al., 2012). Particles from dust storms might also cover farm and grasslands to result in damage to crops and fill the rivers and water channels with aeolian material. After the extreme drought of 1999, the dust activity over Sistan appears to be increasing in both frequency and severity. Over recent years, ten thousands of people have suffered from respiratory diseases and asthma during months of devastating dust storms in the Sistan basin, especially in the cities of Zabol and Zahak and the surrounding villages (Miri et al., 2007). According to the Asthma Mortality Map of Iran, the rate of asthma in Sistan is, in general, higher than in other regions (Selinus et al., 2010).

In order to understand the influence of dust on the atmospheric environment, climatic system and health and to establish effective remedial policies and strategies, it is regarded as necessary to investigate the chemical (composition and mineralogy) characteristics of airborne and soil dust over Sistan. To the best of our knowledge there are currently no published studies about the geochemical characteristics and dust mineralogy, and only a few 
about the geology and potential impact of airborne dust on human health in this region, such as the first PM analysis over Zahedan city (Rashki et al., 2011), the investigation of the sediment loading during major dust events over the Hamoun basin (Jadidoleslami et al., 2011; Rashki et al., 2012) and the effects of droughts and winds on desertification (Ranjbar and Iranmanesh, 2008; Hosseini et al., 2010). Moreover, nearby locations, Bagram and Khowst in Afghanistan, were selected for analyzing the mineralogical dust composition, major and trace elements within the framework of the Enhanced Particulate Matter Surveillance Program (EPMSP) campaign (Engelbrecht et al., 2009). Furthermore, mineralogical and geochemical characteristics of dust were recently examined at Khuzestan province in southwestern Iran (Zarasvandi et al., 2011).

In the present study, an overview of the geological-geochemical characteristics of airborne and soil dust in the Sistan region is given for airborne and soil samples collected during the period August 2009 to August 2010. The chemical constituents during major dust storms over the region are analyzed at two locations, also investigating the relationship between the chemical constituents of the dust storms and those of the inferred (Hamoun) source soils.

\section{Study area}

The Sistan region $\left(30^{\circ} 5^{\prime} \mathrm{N}-31^{\circ} 28^{\prime} \mathrm{N}\right.$ and $\left.61^{\circ} 15^{\prime} \mathrm{E}-61^{\circ} 50^{\prime} \mathrm{E}\right)$ is located in southeastern Iran close to the Iranian borders with Pakistan and Afghanistan (Fig. 1). The region has four cities and 980 villages with total population of more than 400,000. The climate is arid, with low annual average precipitation of $\sim 55 \mathrm{~mm}$ occurring mainly in the winter (December to February) and evaporation exceeding 4000 mmyear $^{-1}$ (Moghadamnia et al., 2004). During summer, the area is under the influence of a low pressure system attributed to the Indian thermal low that extends further to the west as a consequence of the south Asian monsoon system. These low pressure conditions are the trigger for the development of the Levar northerly wind, commonly known as the "120-day wind" (Hossenzadeh, 1997), causing frequent dust and sand storms, especially during summer (June to August) (Goudie and Middleton, 2000; Middleton, 1996) and contributing to the deterioration of air quality (Rashki et al., 2011). Therefore, one of the main factors affecting the weather conditions over the region is the strong winds rendering Sistan as one of the windiest deserts in the world. These winds blow continuously in spring and summer (from May to September), and on 
some days during winter, and have significant impacts on the landscape and the lives of the local inhabitants. Fig. 1 (middle panel) shows a severe dust storm over the Sistan region as observed from the Terra-MODIS satellite's true color image on 15 June 2004. The intense dust plumes form a giant U-shape extending from Sistan into southern Afghanistan and southwestern Pakistan that obscures the surface over much of the region. The pale color of the dust plume is consistent with that of dried wetland soils. The dust is blowing off the dry lake beds that become the Hamoun wetlands during wet years; however, in Fig. 1 (right panel) only a small part of the Hamoun Basin is covered by water. Severe droughts during the past decades, especially after 1999, have caused desiccation of the Hamoun lakes (Whitney, 2006) leaving a fine layer of sediment that is easily lifted by the wind (Ranjbar and Iranmanesh, 2008), thus modifying the basin to one of the most active sources of dust in southwest Asia (Middleton, 1986; Goudie and Middleton, 2006; Esmailli et al., 2006). Therefore, the Hamoun dry lake beds exhibit large similarities with the other two major dust source regions of the world that comprise of dried lakes and topographic lows, i.e. Bodélé depression in Chad (Koren et al., 2006) and lake Eyre in Australia (Baddock et al., 2009). The strong winds blow fine sand off the exposed Hamoun lake beds and deposit it to form huge dunes that may cover a hundred or more villages along the former lakeshore. As a consequence, the wildlife around the lake has been negatively impacted and fisheries have been brought to a halt.

The Hirmand river (also known as Helmand) is the longest river in Afghanistan (ca. 1150 km; catchment $>160,000 \mathrm{~km}^{2}$ ) and the main watershed for the Sistan basin, finally draining into the natural swamp of the Hamoun lakes complex (e.g. Hamoun Saburi, Hamoun Puzak) (Fig. 1). In view of the Hirmand and the surrounding rivers that supply most of the sediments to the Hamoun lakes, a brief encapsulation of the relevant geology of the catchment area in Afghanistan is given. Afghanistan has a very complex geology, encompassing two major relatively young orogenies, Triassic and subsequent Himalayan, resulting in amalgamation of crustal blocks and formation of concomitant ophiolites and younger clastic and carbonate sedimentary rocks as well as basaltic lavas and, more recently, extensive alluvial and Aeolian detritus (website, British Geological Survey; http://bgs.ac.uk/). Supplementary figure 1a shows the geological map of the Sistan area and surroundings. As can be seen, the Sistan 
region and Hamoun dry lake beds are mainly composed of Quaternary lacustrine silt and clay material as well as Holocene fluvial sand, silt and clay. These materials have been carried to the basin by the rivers, while along their courses Neogene fluvial sand, Aeolian sand, silt and clay are the main constituents. Note also the difference in the soil-dust composition between two major desert areas, Registan and Dasht-i-Margo in Afghanistan. The former is composed of Neogene coarse gravels and the latter of Quaternary Aeolian sand. This difference causes the different color in Landsat image (Supplementary Fig. 1b) between these two arid surfaces that contribute to the material deposited in the Sistan region. However, the Registan area has a pale color that differentiates this region from all the others, while at the Hamoun basin white-colored areas are observed, suggesting a dominance of sand, silt and clay. More details about the geology in the Sistan region can be found in Tirrul et al. (1983).



Figure 1. Map of the study area showing the Sistan Basin, Hamoun lakes and the two measuring locations, A and B between Zabol city and the Hamoun dry-bed lakes. 


\section{Methods, data and material samples}

The amount of sediment loading during major dust storms was measured using passive dust samplers fixed on two monitoring towers (at 4 and 8 meters from the ground), with one meter distance between the traps, during the period August 2009 to August 2010 (Rashki et al., 2012). The towers were installed in two open locations near Hamoun $\left(31.10^{\circ} \mathrm{N}, 61.51^{\circ} \mathrm{E}\right.$ and $31.20^{\circ} \mathrm{N}, 61.61^{\circ} \mathrm{E}$ ), and sufficiently far away from any obstacles, so that undisturbed wind flow was entering the samplers (stations A and B in Fig. 1). The dust sampler used in the campaign was developed by the Agricultural and Natural Research Center of Sistan and is a modified version of the SUSTRA sampler (Janssen and Tetzlaff, 1991) and SSDS sampler (Ekhtesasi, 2009). After each measurement, the samplers were evacuated to be ready for measuring the next dust event. The most commonly used passive sampling techniques collect dust using a non-reactive collection pan filled with glass marbles, which serves as the depositional surface (Goossens and Offer, 1994; Reheis and Kihl, 1995). Furthermore, during the summer of 2009 , topsoil samples at depths of $0-5 \mathrm{~cm}$ were collected from different landuse areas in Hamoun and Sistan. These samples were selected and analyzed as they are good indicators of the atmospheric deposition of geochemical elements in the Sistan region.

\subsection{Chemical and mineralogical analysis}

Analyses of the chemical and physical characteristics of dust particles are regarded as essential in studies on the environmental impact of dust storms (Zarasvandi, 2009). Determination of the chemical composition of airborne dust is also necessary for clarifying the likely sources of dust and is important for quantitative climate modeling and understanding the possible effects of dust on health, soils, precipitation, oceanbiogeochemistry and weathering phenomena (Goudie and Middleton, 2006). During the duststorm days in 2009 and 2010, 132 samples of airborne dust were collected at the two stations in the Sistan region. These samples were analyzed at the University of Pretoria, South Africa, in the Stoneman Laboratory (Geology Department) for major and trace elements, and for minerals by applying X-Ray Fluorescence (XRF) and X-Ray Diffraction (XRD) techniques, respectively.

The samples were prepared for XRD analysis using a back loading preparation method. They were analyzed using a PANalytical X'Pert Pro powder diffractometer with X'Celerator detector and variable divergence and receiving slits with Fe filtered $\mathrm{Co}-\mathrm{K} \alpha$ radiation. The 
phases were identified using X'Pert High score plus software. The relative phase amounts (weights \%) were estimated using the Rietveld method (Autoquan Program). Mineral analysis by XRD is the single most important nondestructive technique for the characterization of minerals such as quartz, feldspars, calcite, dolomite, clay, silt and iron oxides in fine dust. Mineral phase analysis by XRD is one of few techniques that is phase sensitive, rather than chemically sensitive, as is the case with XRF spectrometry. Quantitative mineralogical analyses using XRD technique have been performed by a number of scientists over the globe (e.g., Rietveld, 1969; Sturges et al., 1989; Caquineau et al., 1997; Engelbrecht et al., 2009; Zarasvandi, 2009).

The sample preparation for XRF is made up of two methods, pressed powders and fusions. The former samples were prepared for trace element analyses and the latter for major element analyses. Each milled sample $(<75 \mu \mathrm{m})$ was combined with a polyvinyl alcohol, transferred into an aluminum cup and manually pressed to ten tons. The pressed powders were dried at $100^{\circ} \mathrm{C}$ for at least 30 minutes and stored in a desiccator before analyses were conducted. For the fusion method, each milled sample $(<75 \mu \mathrm{m})$ was weighed out in a $1 / 6$ sample to flux (Lithium tetraborate) ratio. These samples were then transferred into mouldable $\mathrm{Pt} / \mathrm{Au}$ crucibles fused at $1050^{\circ} \mathrm{C}$ in a muffle furnace. Aluminum cooling caps were treated with an iodine-ethanol mixture (releasing agent) and placed on top of the crucibles as they cooled. Some samples needed to be treated with an extra $3 \mathrm{~g}$ of flux if they continued to crack.

Finally, all geochemical samples were analyzed using the Thermo Fisher ARL 9400 XP+ Sequential XRF. The Quantas software package was used for the major element analyses and the WinXRF software package was used for the trace element analyses. The concentrations of the major elements are reported as oxides in weight percentages, while the trace element concentrations are reported as elements in parts per million (ppm). All the dust samples, airborne and soil, were subjected to microscopic imaging, while Scanning Electron Microscopy (SEM) images were performed for the airborne dust samples at stations A and B.

\subsection{Enrichment factor analysis}

The calculation of Enrichment Factors (EFs) relative to the Earth's upper crust composition can be used to discriminate between the origins of elements from crustal or non-crustal sources (Zhang et al., 2003). EFs of elements in different particle fractions were determined 
by comparing the concentration of each element against the concentration of a reference (crustal) element to obtain a preliminary idea about possible origin sources, i.e crustal or anthropogenic. Usually $\mathrm{Si}, \mathrm{Al}$ or $\mathrm{Fe}$ is used as the reference element, but there is no universally accepted rule for its choice. In this study, Si was used as the reference element, as done previously by many investigators (Lee and Hu, 1995; Bilos et al., 2001; Manoli et al., 2002; Choi and Bang, 1999; Han et al., 2005; Wang et al., 2007). Estimates of EF) aid in (a) differentiating between element concentrations that originate from human activities and those from natural sources and, in (b) assessing degree of anthropogenic influence (Cong et al., 2007). The appropriateness of choosing Si is attributed to its more significant distribution in coarse particles ( $83 \%$ on average) than other elements, with very low contribution from noncrustal inputs (Wang et al., 2006). The abundance ([E/R] Crust values) of elements in the Earth's crust was taken from Wang et al. (2006). The EFs for crustal material $\left(\mathrm{EF}_{\text {crust }}\right)$ were calculated as follows:

$\mathrm{EF}_{\text {Crust }}=[\mathrm{E} / \mathrm{R}]_{\text {Air }} /[\mathrm{E} / \mathrm{R}]_{\text {Crust }}$

Where $\mathrm{E}$ is the elemental concentration, $\mathrm{R}$ is a reference element $(\mathrm{R}=\mathrm{Si}$ for the present study) of crustal material and $[E / R]_{\text {Air }}$ is the concentration ratio of $E$ to $R$ in a collected aerosol sample, and $[\mathrm{E} / \mathrm{R}]_{\text {Crust }}$ is the concentration ratio of $\mathrm{E}$ to $\mathrm{R}$ in the Earth's crust. Si was used as reference element because it is abundant in the crustal materials, it is usually not of anthropogenic origin and, consequently, values of $\mathrm{EF}_{\mathrm{Si}}$ are close to 1. If $\mathrm{EF}_{\text {Crust }}$ approaches unity, then crustal soils are most likely the predominant source of element E. In practical terms, if the $\mathrm{EF}_{\text {Crust }}$ value is above 10, then the element is considered to be of non-crustal origin, possibly anthropogenic (Scheff and Wadden, 1997; Gao et al., 2002; Wang et al., 2006). $\mathrm{EF}_{\text {Crust }}$ values in the range of 1-5 suggest no significant contribution of anthropogenic sources to the ambient level of these elements. In general, as the $\mathrm{EF}_{\text {Crust }}$ value increases, the non-crustal source contribution also increases.

\section{Results and discussion}

\subsection{Occurrence of dust storms}

Wind erosion and associated dust outflows is a common scenario in Sistan, which is considered as an active dust-storm region all year round, with higher intensity in summer (Jun-Aug). Middleton (1986) reported that over 30 intense dust storms per year originate from Sistan, more than any other area in southwest Asia. Especially during summer, when the 
Hamoun lakes are dry and the wind speed is at its maximum, Sistan becomes a major contributor of dust aerosols over southwest Asia and the northern Arabian Sea (Rashki et al., 2012). Rashki et al. (2012) examined the climatology and meteorology over Sistan via observations from the nearby Zabol meteorological station, reporting that throughout the year the winds are northwesterly in direction with higher intensity during summer, while the sediment loading depends mainly on the duration of dust storms and secondarily on wind speed and direction. In the following sections the dust mineralogy, bulk chemical composition and trace elements are analyzed for samples collected during 15 events of intense dust storms at station A and on 9 days at station B, with their between distance being $\sim 20 \mathrm{~km}$. The dust samples were collected at 4 heights at station A and at 8 heights at station B. Except of the airborne dust samples, the mineralogy of soil samples collected at 16 locations is also analyzed and compared to those of airborne samples.

\subsection{Mineralogical characteristics of dust}

Optical and physical properties of dust are well-defined in north hemisphere and there are also some studies over south hemisphere (e.g. Qin and Mitchell, 2009; Radhi et al, 2010) but less knowledge is available about the spatio-temporal variations of the chemical composition of dust. The mineralogical characteristics of dust samples at stations A and B were obtained by means of XRD analysis. The mineralogy percentage composition averaged at all heights for each day is shown in Fig. 2a, b for stations A and B, respectively. The chemical formulas of the main mineralogical components are given in Usher et al. (2003), as well as the chemical reactions of dust with atmospheric constituents and trace gases during the dust life cycle. The mineralogical composition corresponds to screened samples with diameter $<75 \mu \mathrm{m}$ and can constitute an indication of both regional geology and wind transported dust that is deposited in local soils (Engelbrecht et al., 2009). Furthermore, dust mineralogy has been used for the identification of different source regions over the globe (Claquin et al., 1999; Krueger et al., 2005).

Emphasizing the dust mineralogy at station A, it is seen that the airborne dust is mainly composed of quartz, which is the dominant component (26-40\%) for all the days of observations. Calcareous particles, mainly consisting of calcite, are the second dominant mineralogical component over the site with average mass percentage of $22 \%$, while micas (muscovite) contribute $13 \%$ and plagioclase (albite), 11\%. The remaining components contribute much less to the dust mass, while chlorite $(6.3 \%)$ is apparent in all dust samples 
for all days. The others, i.e. dolomite, enstatite, gypsum, halite, etc are present only at some samples with various percentages. It is quite interesting to note that quartz is much more common over Sistan than the feldspars (plagioclase, microcline and orthoclase).

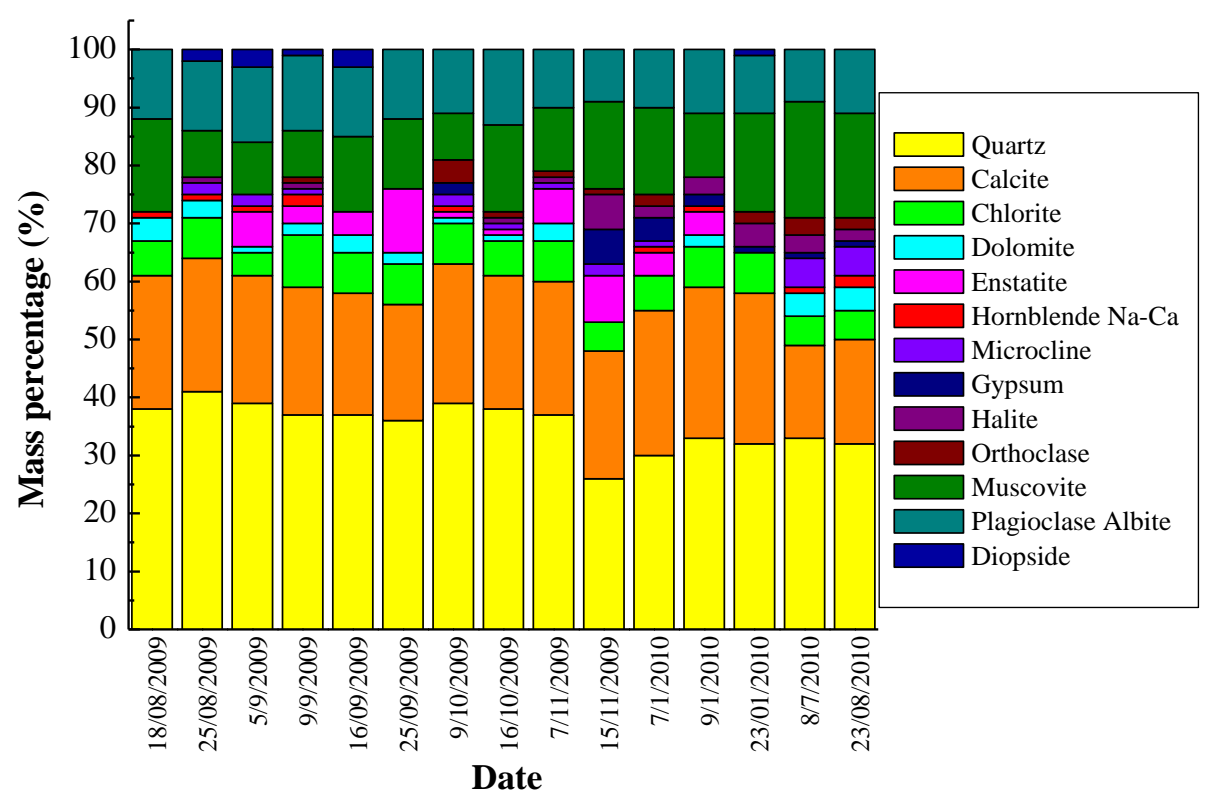

Figure 2a. Mineralogical composition as obtained from XRD analysis for airborne dust samples collected on different days in station A.

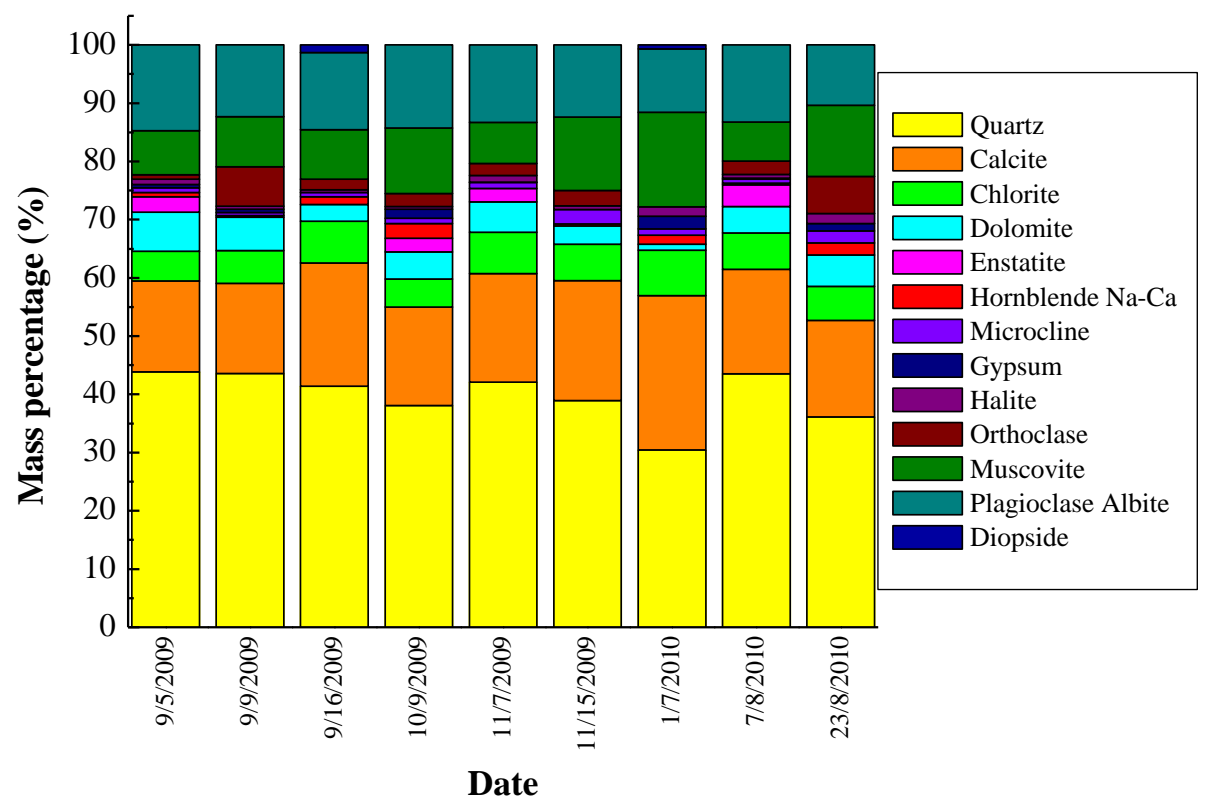

Figure 2b. Same as in Figure 2a, but for the station B. 
The mineralogical analysis for the 9 days recorded data at station B (Fig. 2b) shows more or less similar results to those obtained for station A and, therefore, any discussion will be given on their comparison (Fig. 4). The mineralogical composition has the same descending order as in station A, i.e. quartz (39.8 $\pm 4.4 \%)$, calcite $(18.8 \pm 3.5 \%)$, plagioclase (albite) $(12.7 \pm 1.4 \%)$ and muscovite $(10.1 \pm 3.2 \%)$. On the other hand, dust deposition may influence biogeochemical cycling in terrestrial ecosystems, while dust accumulation in soils can influence texture, element composition and acid neutralizing capacity (Larssen and Carmichael, 2000; Muhs and Benedict, 2006). Furthermore, the chemical and mineralogical composition of soil dust provides useful information about its provenance (Yang et al., 2007), radiative forcing implications (Sokolik and Toon, 1999) and human health effects (Erel et al., 2006). For these reasons, in addition to the airborne dust samples, soil samples were collected at 16 locations around Sistan and Hamoun, at depths ranging from 0 to $5 \mathrm{~cm}$ from the soil crust. The results of soil sample mineralogy are summarized in Fig. 3. From an initial consideration of these results, it is established that the soil samples exhibit similar mineralogy to the airborne dust at both stations, thus suggesting similarity in sources for both airborne and soil dust. On the other hand, some soils in the Sistan region have been primarily formed from dust transported from the Hamoun lakes, presenting large similarities in mineralogy and chemical composition to airborne dust. However, atmospheric chemical reactions involving dust and aerosols of other types can alter the chemical characteristics of dust before its deposition (Dentener et al., 1996). Therefore, the mineralogy of the soil samples may differ significantly in comparison to the results obtained for airborne dust at stations A and B, since some of the soil samples (11 samples) were collected in the Hamoun dried lakes and others (four samples) around stations A and B. 


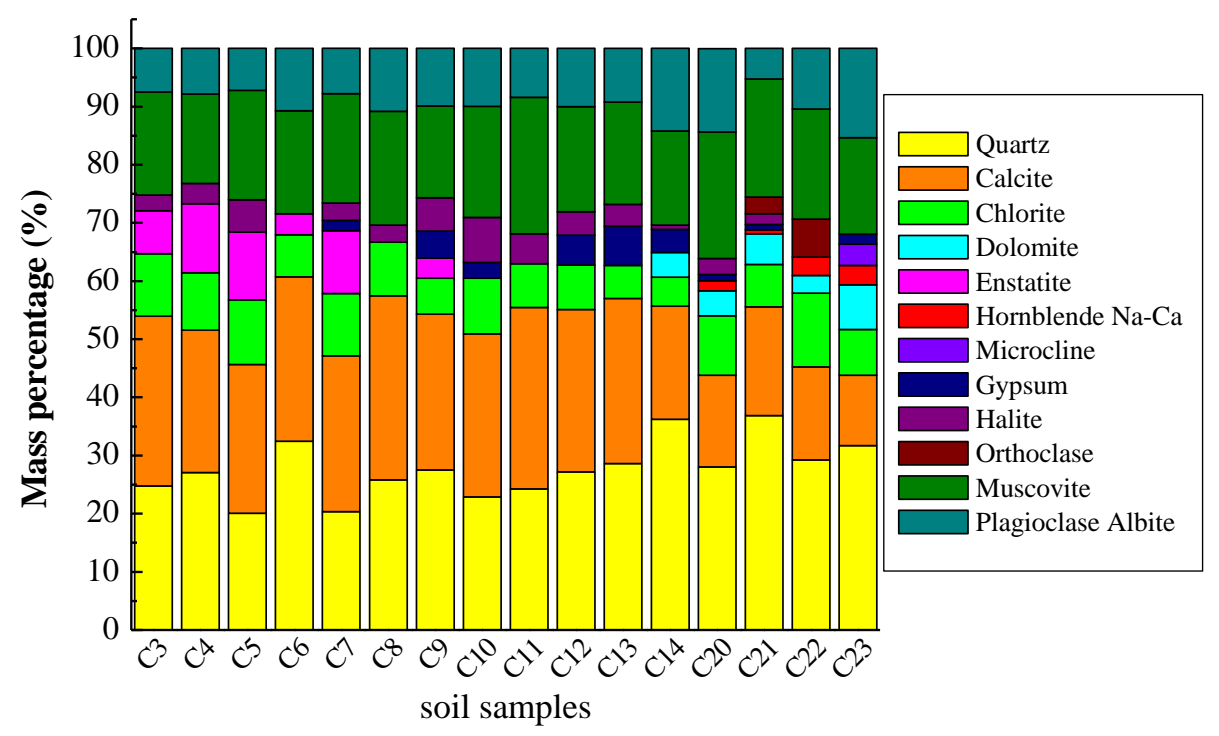

Figure 3. Mineralogical composition as obtained from XRD analysis for soil samples collected at various locations in Hamoun Basin.

Figure 4 summarizes the results from the mineralogical analysis of samples taken at the two stations and from the soil samples, allowing a quantitative comparison between them. The vertical bars correspond to one standard deviation from the mean for both airborne and soil samples. The distance from the source region from whence dust is deposited also influences the particle size distribution, mineralogy and chemical composition of dust. Therefore, generally speaking, at local scales quartz clearly dominates with fractions up to $\sim 50 \%$, while as the distance from the dust source increases, feldspars (plagioclase, microcline) and phyllosilicate minerals (illite and kaolinite) present increased fractions (Arnold et al., 1998; Lawrence and Neff, 2009). However, in our study the dust samples were all obtained within the same area, and therefore are mineralogically similar. Nevertheless, station B, which is located closer to the Hamoun basin, the source of dust exposures, exhibits higher percentages of quartz, while station A (near to Zabol city) exhibits higher concentrations of calcite and muscovite compared to station B. On the other hand, the soil samples exhibit a lower mean percentage for quartz $(27.7 \pm 4.7)$ and higher percentages for calcite, chlorite, halite and muscovite compared to the airborne samples. 


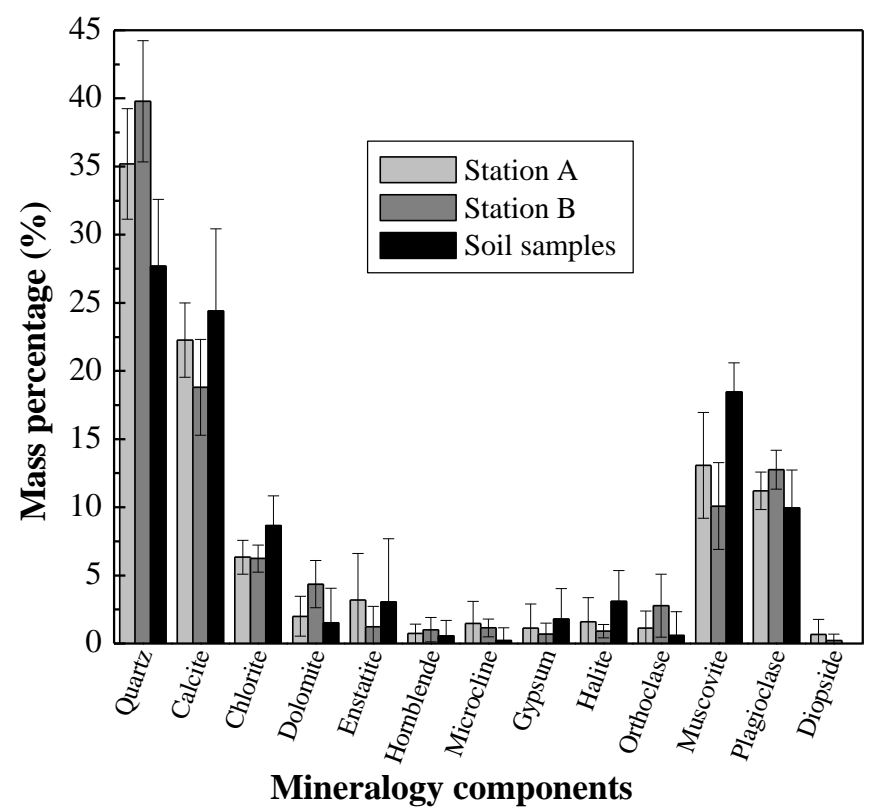

Figure 2. Average mineralogy components for airborne dust samples in stations A and B and for soil samples obtained at various locations in Hamoun Basin. The vertical bars express one standard deviation from the mean.

These mineralogical airborne dust and soil compositions, derived essentially from the Hamoun source region, reflect the composition of the material available from this provenance as well as the relevant grain size characteristics, enabling the wind storms to entrain this material into the lower atmosphere. While most of the minerals (quartz, feldspars of various types, muscovite) can easily be tied to basement-type lithology of generally gneissic-granitic character, others (chlorite, pyroxenes and hornblende) rather suggest mafic parent rocks, as can be inferred from basic mineralogical analysis (e.g., Deer et al., 1966). However, the calcite, dolomite, halite and gypsum suggest evaporite minerals, although both calcite and dolomite can also reflect alteration products of primary acid or mafic rock constituents. The inferred evaporite minerals reflect local derivation of salt from desiccating water bodies in the Hamoun lakes, originally formed from altered transported components via the Hirmand river system. Thus, the semi-quantitative mineral determinations for the airborne dust over the Sistan region support derivation of the particles from well weathered and well eroded (transported) argillaceous alluvium from the extensive Hirmand river system draining Afghanistan and terminating in the Hamoun Basin. The general geology of Afghanistan encompasses extensive terrains of both acidic and mafic rocks, while similar mineralogical composition of dust (i.e. dominance of quartz, but lower percentage of calcite) was found at the Bagram and Khowst sites located in eastern Afghanistan (Engelbrecht et al., 2009). More specifically, they found that these sites are underlain by loess (wind deposited silt), sand, clay 
and alluvium containing gravel. As shown in Fig. 1, as well as in other studies (Engelbrecht et al. 2009; Alam et al., 2011; Rashki et al., 2012), nearly the whole of Afghanistan is affected by the dust storms originating from Hamoun, since the dust plume usually follows a counter-clockwise direction, carrying wind-blown dust towards eastern Afghanistan. Similarly to our findings, the airborne dust at selected locations in southwestern Iran was found to be composed mainly from quartz and calcite, suggesting detrital sedimentary origin, followed by kaolinite and a minor percentage of gypsum (Zarasvandi, 2009). Furthermore, Engelbrecht et al. (2009) found that airborne dust samples derived from poorly drained rivers and lakes in central and southern Iraq contain substantial calcite (33-48\%), quartz, and feldspar with minor chlorite and clay minerals. Previous studies (Schütz and Sebert, 1987; Reheis and Kihl, 1995) have shown that silicate minerals (quartz, feldspars) and phyllosilicates (illite, kaolinite, smectite/montmorillonite clays, chlorite) dominate Aeolian dust. Dust samples may also contain substantial amounts of carbonates, oxides, gypsum, halite and soluble salts, but the quantity and percentage of these minerals are quite variable from site to site.

Supplementary figure 2 shows the altitude variation of the dust mineralogy for dust samples collected during 9 dust-storm days at 8 heights from station B. The mass percentages correspond to the average values during the dust storms over the region. The results show no clear tendency in the altitude variation of the dust mineralogy, at least within the first 8 meters from the ground, suggesting that dust is regionally transported within the lower boundary layer. The surface winds over Sistan control the dust erosion and emission rates (Rashki et al., 2012), thus determining the quantity, chemical and mineralogical composition of dust emitted over the region.

\subsection{Elemental composition of dust}

Knowledge of the chemical composition of airborne dust is necessary for clarifying the likely source regions and is important for quantitative climate modeling, in understanding possible effects on human health, precipitation, ocean biogeochemistry and weathering phenomena (Goudie and Middleton, 2006). Chemical analysis of dust provides valuable information about potentially harmful trace elements such as lead, arsenic and heavy metals $(\mathrm{Co}, \mathrm{Cr}, \mathrm{Cu}$, $\mathrm{Ni}, \mathrm{Pb}$ ). On the other hand, the major-element and ion-chemistry analyses provide estimates of mineral components (Figs. 2-4), which themselves may be hazardous to human health and 
ecosystems and which can act as carriers of other toxic substances. The chemical analysis of dust samples at both stations was performed via XRF analysis for the major oxides (Figs. 5a, b).

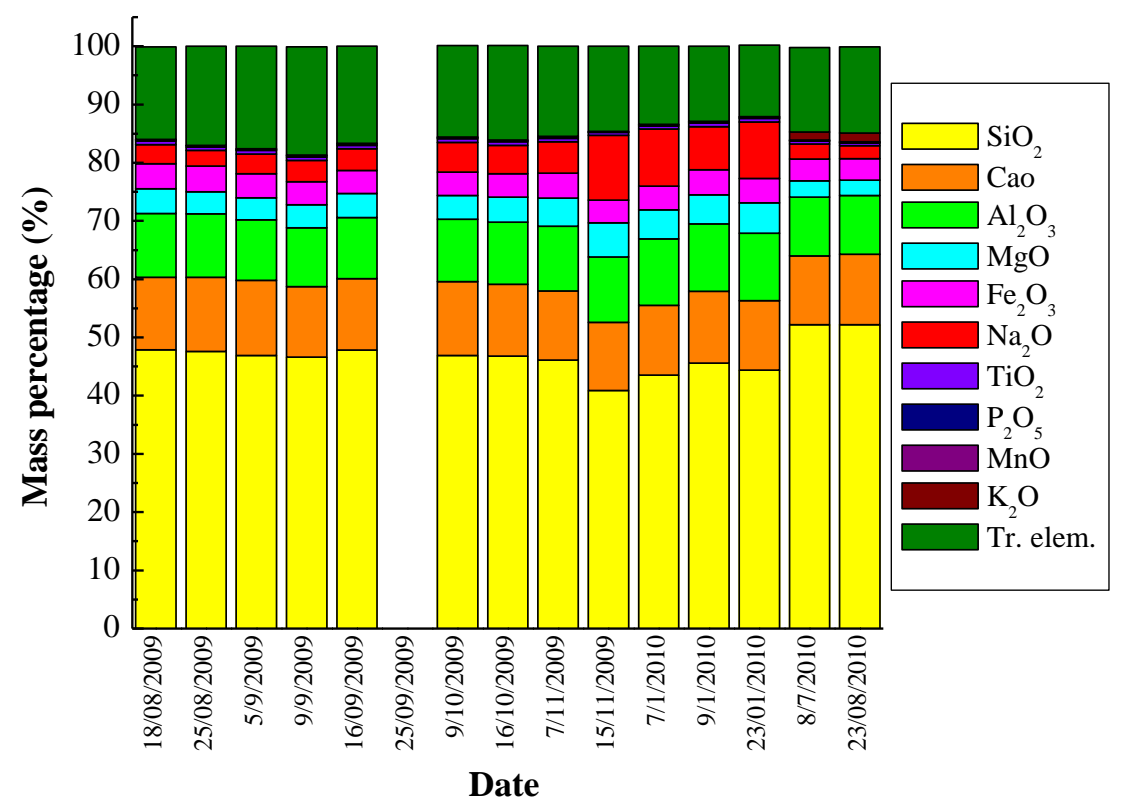

Figure 5a. Major elements (oxides) for airborne dust samples obtained on different days at Station A by means of the XRF analysis.



Figure 5b. Same as in Figure 7a, but for the station B. 
In general, the analysis reveals that all samples at both stations contain major amounts of $\mathrm{SiO}_{2}$, mainly in the mineral quartz, variable amounts of $\mathrm{CaO}$ in the mineral calcite, plagioclase feldspar and to a limited extent in dolomite, as well as substantial $\mathrm{Al}_{2} \mathrm{O}_{3}$ concentrations. More specifically, average major elements of airborne dust at both stations indicate a predominant $\mathrm{SiO}_{2}$ mass component $(46.8-47.8 \%)$ with significant $\mathrm{CaO}$ (1212.2\%) and $\mathrm{Al}_{2} \mathrm{O}_{3}(10.4-10.8 \%)$ contributions; a few percent of $\mathrm{Na}_{2} \mathrm{O}$ (4.2-5.4\%), $\mathrm{MgO}$ (4.3\%) and total iron as $\mathrm{Fe}_{2} \mathrm{O}_{3}(3.8-4.1 \%)$, as well as trace amounts $(<1 \%)$ of $\mathrm{TiO}_{2}, \mathrm{~K}_{2} \mathrm{O}, \mathrm{P}_{2} \mathrm{O}_{5}$ and $\mathrm{MnO}$, while the remaining major elements $\left(\mathrm{Cr}_{2} \mathrm{O}_{3}, \mathrm{NiO}, \mathrm{V}_{2} \mathrm{O}_{5}, \mathrm{ZrO}_{2}\right)$ were not detected by XRF analysis (Figs. 5a, b). When compared to various average shale analyses in the literature (Geosynclinal Average Shale and Platform Average Shale from Wedepohl, 1971; Average Shale from Clarke, 1924; North American Shale Composite from Gromet et al., 1984), the Sistan dust is significantly depleted in $\mathrm{SiO}_{2}, \mathrm{Al}_{2} \mathrm{O}_{3}, \mathrm{~K}_{2} \mathrm{O}$ and total $\mathrm{Fe}$ and significantly enriched in $\mathrm{CaO}, \mathrm{Na}_{2} \mathrm{O}$ and $\mathrm{MgO}$. The $\mathrm{MgO}$ is largely contained in dolomite and, to a lesser extent, in clay minerals such as palygorskite and montmorillonite (Goudie and Middleton, 2001; Engelbrecht et al., 2009). These components can be ascribed to the importance of evaporite minerals such as calcite, dolomite, halite and gypsum (as also suggested by the mineralogical analysis) inferred to have come from the desiccation taking place in the Hamoun dust source region. Furthermore, the elevated values for the trace elements $\mathrm{Cl}, \mathrm{F}$ and $\mathrm{S}$ (Table 1) support the latter postulate as it would be expected from an evaporite-rich source for deflation of dust (e.g., Talbot and Allen, 1996). Similar to the present findings, Engelbrecht et al. (2009) determined a high fraction of $\mathrm{SiO}_{2}$ in silt, less $\mathrm{CaO}$ in calcite and slightly more $\mathrm{Al}_{2} \mathrm{O}_{3}$ in clay minerals at the Khowst site. At both Afghanistan sites (Bagram and Khowst), the $\mathrm{SiO}_{2}$ was dominant with fractions of about 50-55\%, followed by $\mathrm{Al}_{2} \mathrm{O}_{3}, \mathrm{CaO}$ and $\mathrm{MgO}$.

By comparing the major elements of different dust storms, some interesting relationships are revealed. More specifically, on days (e.g. 15/11/2009, 7/1/2010, 23/1/2010) (Fig. 5a) when airborne dust was relatively depleted in $\mathrm{SiO}_{2}$, enhanced $\mathrm{MgO}$ and, particularly $\mathrm{Na}_{2} \mathrm{O}$ values were recorded. Conversely, when $\mathrm{SiO}_{2}$ values were higher (e.g. 8/7/2010, 23/8/2010), both $\mathrm{MgO}$ and $\mathrm{Na}_{2} \mathrm{O}$ contributions dropped. This suggests that certain intense dust storms were richer in evaporite source material (i.e., elevated $\mathrm{MgO}$ and $\mathrm{Na}_{2} \mathrm{O}$ ) coming from Hamoun dried lake beds, while others had more silica, reflecting weathered rock detritus from the Hirmand river and Afghanistan mountains. An explanation of these variable chemical compositions of dust samples is a real challenge, but it is postulated here that they may reflect 
local desiccation cycles and, possibly, even micro-climatic changes in the Hamoun-lakes dust source region. Excessive desiccation of the lakes would enhance potential evaporite minerals for deflation in drier periods, while in wetter periods, airborne dust would logically have been derived more from weathered fluvial detritus rich in $\mathrm{SiO}_{2}$.

Figure 6 summarizes the results of the elemental compositions determined by XRF analysis at both stations. For comparison reasons, the mean elemental composition found at several sites in southwestern Iran (Khuzestan province) (Zarasvandi et al., 2009) is also shown. The vertical bars express one standard deviation from the mean. Concerning the major elemental oxides over Sistan, both stations exhibit similar results, well within the standard deviations, suggesting that the transported dust over Sistan is locally or regionally produced with similarity in source region. In contrast, the mean elemental composition of airborne dust over Khuzestan province exhibits remarkable differences from that over Sistan, revealing various source regions and dust mineralogy. More specifically, the $\mathrm{SiO}_{2}$ percentage is significantly lower and highly variable over Khuzestan, which is also characterized by higher contributions of $\mathrm{Na}_{2} \mathrm{O}, \mathrm{MgO}$ and $\mathrm{K}_{2} \mathrm{O}$ compared to Sistan. The dust storms over southwestern Iran may originate from local sources as well as being transported over medium- and longranges from different sources located in Iraq as well as in Arabian Peninsula. A comparative study of the mineralogy and elemental composition of airborne dust at several locations in Iraq, Kuwait and the Arabian Peninsula (Engelbrecht et al., 2009) has shown significantly variable contributions, suggesting differences in overall geology, lithology and mineralogy of these regions. In further contrast, airborne dust over Sistan seems to have its individual characteristics originating from local and well-defined sources. 


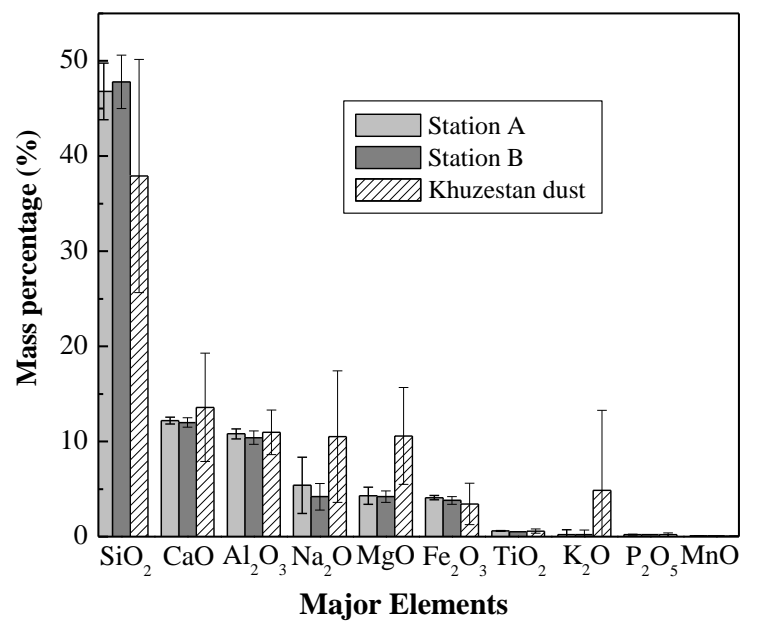

Figure 6. Average X-ray fluorescence (XRF) results for major dust elements in stations A and B. Similar results obtained in Khuzestan Province, southwestern Iran (Zarasvandi et al., 2009) are also shown for comparison reasons.

The Earth's crust is dominated by silicon and aluminum oxides. Numerous studies (Goudie and Middleton, 2001, 2006 and references therein) reviewing the elemental composition of airborne dust over the globe report that mineral dust is composed of $\sim 60 \% \mathrm{SiO}_{2}$ and $10-15 \%$ $\mathrm{Al}_{2} \mathrm{O}_{3}$. The contribution of other oxides, i.e. $\mathrm{Fe}_{2} \mathrm{O}_{3}(\sim 7 \%), \mathrm{MgO}(\sim 2.5 \%)$ and $\mathrm{CaO}(\sim 4 \%)$, are, in general, more variable depending on source location. Furthermore, the review study of Usher et al. (2003) showed that airborne dust samples collected over the globe have fairly small variations in elemental composition. The $\mathrm{CaO}$ concentrations over Sistan are found to be much higher than those (5.5\%) summarized in Usher et al. (2003).

\subsection{Trace elements}

The average concentrations of trace elements (in ppm) in the dust samples collected during major dust storms at stations $\mathrm{A}$ and $\mathrm{B}$ are summarized in Table 1, as obtained from XRF analysis. The results show that the dominant trace elements over Sistan are F and $\mathrm{Cl}$, with the former being dominant in the vast majority of the dust events at station A. However, on two days $(8 / 7 / 2010$ and $23 / 8 / 2010)$ the $\mathrm{Cl}$ concentrations were extremely large, thus controlling the average value; there is a lack of observations at station B on $23 / 8 / 2010$, thus the lower overall $\mathrm{Cl}$ concentration. Note that on both these days, the $\mathrm{SiO}_{2}$ component is large, while $\mathrm{MgO}$ and $\mathrm{Na}_{2} \mathrm{O}$ are low (Fig. 5a). The dominance of chlorine indicates soil salinization in the Hamoun basin and along the Hirmand river and its tributaries. Furthermore, S exhibits higher concentration at station $\mathrm{A}$, while for the other elements the concentrations between the two stations are more or less similar. The concentrations of potentially harmful and toxic 
elements, like $\mathrm{Cs}, \mathrm{Pb}$ and $\mathrm{As}$ are, in general, low at both stations; however, $\mathrm{Ba}, \mathrm{Cr}$ and $\mathrm{Zn}$ present moderate concentrations.

The analysis of the major element ratios provides essential knowledge of the dust chemical composition and source region. The ratios of $\mathrm{Si} / \mathrm{Al}$ at stations $\mathrm{A}$ and $\mathrm{B}$ are similar $(7.8 \pm 0.8$ and $8.3 \pm 0.9$, respectively), due to the presence of silicate and aluminosilicate minerals in

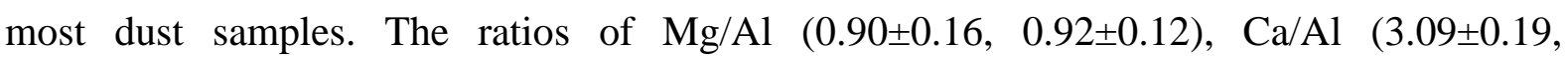
$3.12 \pm 0.19)$ and $\mathrm{Fe} / \mathrm{Al}(0.51 \pm 0.02,0.49 \pm 0.01)$ at the two stations suggest contributions of clays and Ca-rich (calcite) minerals to the chemical compositions of airborne dusts. In contrast, the Fe/Al ratio is low over Sistan and is nearly half of that found for airborne dust over southwestern Iran and several locations over the globe (Zarasvandi, 2009), but is comparable to that found over central Asia (Kreutz and Sholkovitz, 2000). It should be noted that this ratio remains nearly invariant, ranging from 0.47 to 0.54 , for all the collected dust samples at both stations and can be a good surrogate for the dust source region, since any variation in Fe/Al mainly corresponds to variations in clay minerals and not to coating during dust transportation (Goudie and Middleton, 2006). In contrast, the $\mathrm{Ca} / \mathrm{Al}$ ratio exhibits the highest variations from sample to sample (2.80-3.46), since it is influenced by particle size, with higher values as particle-size increases (Zarasvandi et al., 2009). Synoptically, all the ratio values and the low standard deviations suggest similarity in geochemical characteristics over Sistan and a uniform source of airborne dust.

Table 1. Average X-ray fluorescence $(\mathrm{XRF})$ values for trace elements of airborne dust for stations A and B.

\begin{tabular}{lll}
\hline Trace Elements & & \\
\hline Parts per million $(\mathrm{ppm})$ & Station $\mathrm{A}$ & Station B \\
$\mathrm{Cl}$ & 28670 & 15047 \\
$\mathrm{~F}$ & 13938 & 13456 \\
$\mathrm{~S}$ & 4445 & 2506 \\
$\mathrm{Ba}$ & 210 & 253 \\
$\mathrm{Sr}$ & 154 & 125 \\
$\mathrm{Zr}$ & 83 & 76 \\
$\mathrm{Cr}$ & 70 & 84 \\
$\mathrm{~V}$ & 69 & 69 \\
$\mathrm{Zn}$ & 57 & 51 \\
$\mathrm{La}$ & 30 & 32 \\
$\mathrm{Rb}$ & 24 & 19 \\
$\mathrm{Ni}$ & 18 & 16 \\
$\mathrm{Ce}$ & 17 & 16 \\
$\mathrm{Cs}$ & 14 & 13 \\
$\mathrm{Sc}$ & 11 & 11 \\
$\mathrm{Cu}$ & 11 & 11 \\
$\mathrm{~Pb}$ & & \\
\hline
\end{tabular}




\subsection{Enrichment factor analysis}

The EFs for major and trace elements were calculated via the procedure described in section 3.2 for all the airborne dust samples at both stations (Supplementary table 1). The results show that the EF values of the main elements $\mathrm{Al}, \mathrm{Ca}$ and $\mathrm{Fe}$ are close to unity, indicating that these elements have not been enriched yet and are composed from natural soil materials. The EF values of elements $\mathrm{S}, \mathrm{Zn}$ and As are well below unity suggesting that these elements were not affected by human activities. The overall analysis reveals that the elements found in the dust originate from natural sources and that they are not affected by human activities when they are transported over Sistan. The EF values for the major and trace elements shown in Supplementary table 1 are more or less similar to those reported by Lawrence and Neff (2009) summarizing the results of several studies over the globe. In contrast, Zarasvandi et al. (2009) found that the trace elements $\mathrm{Na}, \mathrm{Ni}, \mathrm{Co}, \mathrm{Ba}$ and $\mathrm{Cr}$, are of anthropogenic origin $(E F>10)$ in southwestern Iran. The main reason for this discrepancy is that the abovementioned trace elements, and particularly the $\mathrm{Ba}$, are associated with anthropogenic and industrial (oil and gas drilling) activities, which are absent in the Sistan region.

\subsection{SEM analysis}

Supplementary figure 3 summarizes some microscope images as well as the respective Scanning Electron Microscopy (SEM) images for both airborne and soil dust samples collected over the Sistan study area (see Figure caption for details). The microscope images reveal various shapes and colors of airborne and soil dust over the region which were selected for this summary figure. Note the larger dust particles, associated with higher quartz and dolomite and lower calcite mass percentages, having prismatic and crystalline shapes (second row, left). On the other hand, the microscope images corresponding to airborne dust taken at stations $\mathrm{A}$ and $\mathrm{B}$ at heights $4 \mathrm{~m}$ and $8 \mathrm{~m}$, respectively (first and third rows) show much smaller dust particle sizes and somewhat of a coating between the particles. Both these samples have a lower quantity of quartz and plagioclase (albite) and higher percentages of calcite, chlorite and muscovite than the previous case (larger particles). The two soil samples collected from the Sistan agricultural lands and in the Hamoun Basin (last row) present remarkable differences in the mineralogy and chemical composition, suggesting that the soil in Hamoun is mainly composed of evaporite minerals with high concentrations of $\mathrm{Na}_{2} \mathrm{O}$. Furthermore, the similar mineralogy and chemical dust composition of the soil sample from Hamoun and the airborne dust sample taken at Zabol during a major dust storm on 9 January 2010 must be 
emphasized, suggesting not only that the source region of this particular dust outflow was the Hamoun basin but that the alluvial and lacustrine material from Hamoun is deposited widely over the whole Sistan region. In general, higher $\mathrm{SiO}_{2}$ values in soil crust samples are accompanied by elevated $\mathrm{CaO}$ and total $\mathrm{Fe}$ values, while there is a strong inverse relationship ( $\mathrm{r}=-0.87$ ) between $\mathrm{SiO}_{2}$ and $\mathrm{Na}_{2} \mathrm{O}$ values. Moreover, $\mathrm{SiO}_{2}$ is inversely correlated with both $\mathrm{MgO}(\mathrm{r}=-0.96)$ and $\mathrm{Al}_{2} \mathrm{O}_{3}(\mathrm{r}=-0.73)$, while all the above correlations are statistically significant at $95 \%$ confidence level. These results clearly indicate that soil-forming processes downwind of the airborne sampling stations have radically altered the chemistry of the deposited air-transported dust; particularly, sodium and silica components are subject to rapid fluctuations from one sample locality to another. Taking into account that silica will essentially be related to fine air-transported quartz silt particles while sodium reflects evaporate material as well as some micas and feldspar minerals, the role of dynamic sorting processes during sedimentation may have played an important role in coating samples. On the other hand, the influence of rain may also be important in altering soil crust compositions (Zarasvandi et al., 2009).

In general, all SEM images show that the dust samples have non-spherical, irregular, crystalline prismatic and rhombic shapes, as do those observed over Khuzestan province, southwestern Iran (Zarasvandi et al., 2009). The dust size is, in the vast majority of the cases, much larger than $10 \mu \mathrm{m}$. Previous study analyzing the dust particle size at stations A and B (Rashki et al., 2012) showed that the dust mode size was $\sim 30 \mu \mathrm{m}$ at station A and $\sim 70 \mu \mathrm{m}$ at station B, due to closer proximity of the latter to the dust source region (Hamoun basin). However, in some cases the airborne dust is composed of smaller particles with mean diameters of about 1-3 $\mu \mathrm{m}$. In general, the smaller particles, which are composed mainly from clay minerals, seem to be more spherical, while the larger prismatic and irregular shapes are composed mainly of gypsum and quartz, respectively, as also shown in southwestern Iran (Zarasvandi et al., 2009).

\section{Conclusions}

To fully understand mineral dust characteristics and the potential impact to human health, dust mineralogy and geochemical properties were examined in the Sistan region, southeastern Iran by collecting airborne samples at two stations and soil samples from several locations over Sistan and the Hamoun basin. The Sistan region is an ideal site to study the nature of dust storms as it receives large amounts of fine alluvial material from the extended Hirmand 
river system draining much of the Afghanistan highlands, which comprise crystalline basement rocks, Phanerozoic sediments and extensive flood basalts. As a result, large quantities of quartz-rich, feldspar- and mica-bearing silt, as well as mafic material from flood basalt sources and carbonate minerals from dolomites, are transported to the Hamoun wetlands in northern Sistan. Due to droughts at Hamoun and large irrigation projects upstream on the river catchment, extensive desiccation has occurred in the wetlands resulting in large dry lake environments. These have produced large quantities of evaporite minerals to add to the alluvial silts, and the combination of these materials provides the provenance for the airborne dust.

Dust aerosol characterization included chemical analysis of major and trace elements by XRF and mineral analysis by XRD. The results showed that quartz, calcite, muscovite, plagioclase and chlorite are the main mineralogical components of the dust, in descending order, over Sistan, and were present in all the selected airborne dust samples. In contrast, significantly lower percentages for enstatite, halite, dolomite, microcline, gypsum, diopside, orthoclase and hornblende were found, since these elements occurred only in some of the samples at both stations. On the other hand, $\mathrm{SiO}_{2}, \mathrm{CaO}, \mathrm{Al}_{2} \mathrm{O}_{3}, \mathrm{Na}_{2} \mathrm{O}, \mathrm{MgO}$ and $\mathrm{Fe}_{2} \mathrm{O}_{3}$ were the major elements characterizing the dust, while large amounts of $\mathrm{F}, \mathrm{Cl}$ and $\mathrm{S}$ were also found as trace elements. The mineralogy and chemical composition of airborne dust at both stations were nearly the same and quite similar to the soil samples collected at several locations downwind. This suggests that the dust over Sistan is locally emitted, i.e. from the Hamoun basin, and in a few cases can also be long-range transported to distant regions. On the other hand, individual dust storms showed significant differences between either evaporite-dominated aerosols or those characterized by deflation from alluvial silts. These possibly reflect either localized climatic cyclicity or desiccation cycles. However, in some cases the soil samples showed poor comparisons with aerosol compositions, suggesting that dynamic sorting, soil-forming processes and climatic influences, such as rainfall, altered the mineralogy and chemistry in these partially Aeolian deposits. Sistan is also an ideal site for studying dust storms and enrichment factors relative to crustal norms, the latter suggesting that the dust is essentially of crustal rather than anthropogenic origin. SEM analyses of the samples indicated that airborne dust has rounded irregular, prismatic and rhombic shapes, with only the finer particles and a few cases of the coarser dust being spherical. 


\section{Acknowledgements}

The authors are indeed grateful to the scientists and technical staff at the Natural and Agricultural Research Centre of Sistan that established and maintain the two dust sampling stations in the Sistan region, as well as for providing data from the Zabol meteorological station via the Iran Meteorological Organization website. The authors also acknowledge the personnel of the Geology laboratory of the University of Pretoria for mineralogy and chemical analyses of the dust samples.

\section{References}

Alam, K., Qureshi, S., Blaschke, T., 2011. Monitoring Spatio-temporal aerosol patterns over Pakistan based on MODIS, TOMS and MISR satellite data and a HYSPLIT model. Atmos. Environ., 45, 4641-4651.

Andreae, M.O., 1996. Raising dust in the greenhouse. Nature 380, 389-390.

Arnold, E., Merrill, J., Leinen, M., and King, J.: 1998. The effect of source area and atmospheric transport on mineral aerosol collected over the north pacific ocean, Global Planet Change, 18, 137-159

Baddock, M.C., Bullard, J.E., Bryant, R.G., 2009. Dust source identification: a comparison of techniques. Remote Sens. Environ. 113, 1511-1528.

Bergametti, G., Gomes, L., Coudé-Gaussen, G., Rognon, P., Le Coustumer, M.-N., 1989. African dust observed over Canary islands: Source-regions identification and transport pattern for some summer situations. J. Geophys. Res., 94, D12, 14855-14864.

Bilos, C., Colombo, J.C., Skorupka, C.N., Presa, M.J.R., 2001. Sources, distribution and variability of airborne trace metals in La Plata City area, Argentina. Environ. Pollut. $111,149-158$.

Biscaye, P. E., \& Grousset, F. E. 1998. Ice-core and deep-sea records of atmospheric dust. In A. Busacca (Ed.), Dust aerosols, loess soils, and global change (pp. 101-103). College Agric. Home Econ. Misc. Publ. MISC0190 (1998). Pullman, WA: Washington State Univ.

Caquineau S, Magonthier MC, Gaudichet A, Gomes L. 1997. An improved procedure for the X-ray diffraction analysis of low-mass atmospheric dust samples. Eur. J. Mineral. 9: 157-166.

Charlson, R. J., S. E. Schwartz, J. M. Hales, R. D. Cess, J. A. Coakley, Jr., J. E. Hansen, and D. J. Hofmann, 1992: Climate forcing by anthropogenic aerosols. Science, 255, 423430.

Choi, M. S., \& Bang, E. J. 1999. Trace metals in airborne particulate collected at Cheju Island, Korea. Journal of Korean Society for Atmospheric Environment, 15, 727- 738.

Chow, J. C., Watson, J. G., Ashbaugh, L. L., \& Magliano, K. L. 2003. Similarities and differences in PM10 chemical source profiles for geological dust from the San Joaquin Valley, California. Atmospheric Environment, 37, 1317- 1340.

Christopher, B.K., John M. O. 2004. Elemental Analysis of Sub-Hourly Ambient Aerosol Collections, Aerosol Science and Technology, Volume 38, Issue 3, 205-218

Claquin, T., Schulz, M., Balkanski, Y.J., 1999. Modeling the mineralogy of atmospheric dust sources. Journal of Geophysical Research-Atmospheres 104 (D18), 22243-22256.

Clarke, F. W., 1924. Bull. U.S. geol. Surv., 700, p. 29. 
Cong, Z., Kang, S., Liu, X., Wang, G., 2007. Elemental composition of aerosol in the Nam Co region, Tibetan Plateau, during summer monsoon season. Atmospheric Environment 41, 1180-1187.

Dalmeida, G.A., 1987. On the variability of desert aerosol radiative characteristics. Journal of Geophysical Resarch 92, 3017-3026.

Deer, W. A., Howie, R. A. and Zussman, J.: 1966, An Introduction to the Rock Forming Minerals, Longmans, pp. 528.

Dentener, F.J., Carmichael, G.R., Zhang, Y., Lelieveld, J., Crutzen P.J. 1996, Role of mineral aerosol as a reactive surface in the global troposphere, Journal of Geophysical Research-Atmospheres, 101 (D17) pp. 22869-22889

Ekhtesasi, M.R., 2009. National project of monitoring of wind erosion and sand storm in Iran, forests and range and watershed organization of Iran (Persian language)

Engelbrecht J.P, McDonald E.V, Gillies, J.A, Jayanty RKM, Casuccio, G., Gertler, A.W. 2009, Characterizing mineral dusts and other aerosols from the Middle East-Part 1: Ambient sampling.Inhalation Toxicology 21:297 -326

Erel,Y., Dayan,U., Rabi, R., Rudich,Y., Stein,M., 2006. Trans boundary transport of pollutants by atmospheric mineral dust. Environmental Science \& Technology 40 (9), 2996-3005.

Esmaili, O and Tajrishy, M, 2006, Results of the 50 year ground-based measurements in comparison with satellite remote sensing of two prominent dust emission sources located in Iran, Proc. SPIE 6362, 636209; http://dx.doi.org/10.1117/12.692989

Frank, J.D., Gregory, R.C., Yang, Z., et al., 1996. Role of mineral aerosol as a reactive surface in the global troposphere. Journal of Geophysical Research 101 (D17), 22,86922,889 .

Ganor, E., Foner, H.A., \& Gravenshorst, G. 2003. The amount and nature of the dust on Lake Kinneret (the Sea of Galilee), Israel: flux and fractionation. Atmospheric Environment, $37,4301-4315$.

Gao, X. J., Zhao, Z. C. and Giorgi, F. 2002, Changes of extreme events in regional climate simulations over East Asia, Adv. Atmos. Sci., 19(5), 927- 942.

Goossens, D., Offer, Z.Y., 1994. An evaluation of the efficiency of some eolian dust collectors. Soil Technology 7 (1), 25-35.

Goudie, A.S., Middleton, N.J., 2000. Dust storms in south west Asia. Acta Universitatis Carolinae, Supplement 73-83.

Goudie, A.S., Midelton, N.J., 2006. Desert dust in the global system, Springer. 2006.

Gromet, L P, Dymek, R.F., Haskin, L.A., and Korotev, R.L. 1984) The "North American shale composite": Its compilation, major and trace element characteristics. G eochimica et Cosmochimica Acta, 48,2469- 2482

Han, J. S., Moon, K. J., Ryu, S. Y., Kim, Y. J., \& Perry, D. 2005. Source estimation of anthropogenic aerosols collected by a DRUM sampler during spring of 2002 at Gosan, Korea. Atmospheric Environment, 39, 3113-3125. doi:10.1016/j.atmosenv.2005.01.047.

Hoseini, S. M., Ekhtesasi, M.R., Bazi, KH. R., 2010. Study of types and intensity of effective factors in desertification of the Sistan ( Case study Natak region), Iranian journal of Geografic Space; 10(31):119-136.

Hossenzadeh, S.R., 1997. One hundred and twenty days winds of Sistan. Iran J. Res. Geography 46,103-127.

Jadidoleslami, M., Rahanama Rad, J., Basirani N., 2011. The origin of Aeolian sediments in the Chahnimeh of Zabol. Appl. Geology, 7(1), 9-16.

Janssen, W. and Tetzlaff, G., 1991. Entwicklung und Eichung einer registrierenden Suspensionsfalle. Zeitschrift für Kulturtechnik und Landesentwicklung 32, 167-180. 
Jones, P., Charlson, R., Rodhe, H., 1995. In: Houghton, J.T., et al. (Eds.), Aerosols in Climate Change 1994. Cambridge University Press, New York

Kidwell, C. B. and Ondov, J. M. 2001. Development and Evaluation of a Prototype System for Collecting Sub-Hourly Ambient Aerosol for Chemical Analysis. Aerosol Sci. Technol., 35: 596-6

Koren, I., Y. J. Kaufman, R. Washington, M. C. Todd, Y. Rudich, J. V. Martins, and D. Rosenfeld 2006, The Bodélé depression: a single spot in the Sahara that provides most of the mineral dust to the Amazon forest

, Environ. Res. Lett., 1. 1-5Kreutz, K. and Sholkovitz, E. 2000. Major element, rare earth element, and sulfur isotopic composition of a high-elevation firn core: Sources and transport of mineral dust in central Asia. Geochemistry, Geophysics, Geosystems 1(11).1525-2027.

Krueger, B.J., Grassian, V.H., Cowin, J.P., Laskin, A., 2005. Heterogeneous chemistry of individual mineral dust particles fromdifferent dust source regions: the importance of particle mineralogy. Atmospheric Environment 39 (2), 395-395.

Larney, F. J., Leys, J. F., Muller, J. F., \& McTainsh, G. H. 1999. Dust and endosulfan deposition in cotton-growing area of Northern New South Wales, Australia. Journal of Environmental Quality, 28, 692-701.

Larssen, T., Carmichael, G.R., 2000. Acid rain and acidification in China: the importance of base cation deposition. Environmental Pollution 110 (1), 89-102.

Lawrence, C.R. and Neff, J.C. 2009. The contemporary physical and chemical flux of aeolian dust: A synthesis of direct measurements of dust deposition. Chemical Geology 267: 46-63.

Lee, K. H., \& Hu, C. G. 1995.. A study on chemical composition of dustfall sampled in Cheju area: 2. Identification of source. Journal of Korean Society for Atmospheric Environment, 15, 101-111.

Lioy, P. J., Freeman, N. C. G., \& Millette, J. R. 2002. Dust: A metric for use in residential and building exposure assessment and source characterization. Environmental Health Perspectives, 110, 969-983.

Manoli, E., Voutsa, D., Samara, C., 2002. Chemical characterization and source identification apportionment of fine and coarse air particles in Thessaloniki, Greece. Atmos. Environ. 36, 949-961.

McConnell, C.L., Highwood, E.J., Coe, H., Formenti, P., Anderson, B., Osborne, S., Nava, S., Desboeufs, K., Chen, G., Harrison, M.A.J., 2008. Seasonal variations of the physical and optical characteristics of Saharan dust: Results from the Dust Outflow and Deposition to the Ocean (DODO) experiment. J. Geophys. Res., 113, D14S05, doi:10.1029/2007JD009606.

Middleton, N. J., 1986. Dust storms in the Middle East. J. Arid Environ. 10, 83-96.

Miri, A., Ahmadi, H., Ghanbari, A., Moghaddamnia, A., 2007. Dust Storms Impacts on Air Pollution and Public Health under Hot and Dry Climate. Int. J. Energy and Environ. 2, 1.

Mishra, S.K., Tripathi, S.N., 2008. Modeling optical properties of mineral dust over the Indian Desert. J. Geophys. Res., 113, D23201, doi:10.1029/2008JD010048.

Moghaddamnia, A., Ghafari, M.B., Piri, J., Amin.S., Han. D., 2009. Evaporation estimation using artificial neural networks and adaptive neuro-fuzzy inference system techniques. Adv. Water Resources 32, 88-97.

Muhs, D.R., Benedict, J.B., 2006. Eolian additions to late quaternary alpine soils, Indian Peaks Wilderness Area, Colorado Front Range. Arctic Antarctic and Alpine Research 38 (1), 120-130. 
Nastos, P.T., Paliatsos, A.G., Anthracopoulos, M.B., Roma, E.S., Priftis, K.N., 2010. Outdoor particulate matter and childhood asthma admissions in Athens, Greece: A time-series study. Environmental Health: A Global Access Science Source 9, art. no. 45, doi:10.1186/1476-069X-9-45.

Prospero, J. M. 1999. Long term measurements of the transport of African mineral dust to the south-eastern United States: Implications for regional air quality. Journal Geophysical Research, 104, 15917-15927.

Qin, Y., and Mitchell, R.M., 2009. Characterisation of episodic aerosol types over the Australian continent, Atmos. Chem. Phys., 9, 1943-1956

Radhi, M., Box, M. A., Box, G. P., Mitchell, R. M., Cohen, D. D., Stelcer, E., Keywood, M. D., 2010. Optical, physical and chemical characteristics of Australian continental aerosols: results from a field experiment, Atmos. Chem. Phys., 10, 5925-5942

Ranjbar, M., and Iranmanesh, F. 2008. Effects of "Drought" on "Wind Eroding and Erosion" in Sistan Region with use of Satellite Multiple Images. WSEAS, ISSN: 1792-4294.

Rashki, A., Rautenbach, C.J.deW., Eriksson, P.G., Kaskaoutis, D.G., Gupta, P., 2011. Temporal changes of particulate concentration in the ambient air over the city of Zahedan, Iran. Air Quality, Atmosphere \& Health. DOI: 10.1007/s11869-011-0152-5

Rashki, A., Kaskaoutis, D.G., Rautenbach, C.J.deW., Eriksson, P.G.,Giang, M, Gupta, P., 2012. Dust storms and their horizontal dust loading in the Sistan region, Iran. Aeolian Research doi:10.1016/j.aeolia.2011.12.001

Reheis, M.C., Kihl, R., 1995. Dust deposition in southern Nevada and California, 19841989-relations to climate, source area, and source lithology. Journal of Geophysical Research-Atmospheres 100 (D5), 8893-8918.

Rietveld H.M. 1969. A profile refinement method for nuclear and magnetic structures. J. ppl. Crystallogr.2:65-71.

Rosenfeld, D., Lohmann, U., Raga, G. B., O’Dowd, C. D., Kulmala, M., Fuzzi, S., Reissell, A., Andreae, M. O., 2008. Flood or Drought: How do aerosols affect precipitation?. Science, 321, 1309; DOI: 10.1126/science.1160606.

Scheff, P.A., Wadden, R.A., Ticho, K.K.L., Nakonechniy, J.J., Prodanchuk. M., and Hryhorczuk, D.O., 1997, Toxic air pollutants in chernivtsi, Ukraine. Environmental International, 23 3, 273-290;

Schütz,L., Sebert,M., 1987, Mineral aerosols and source identification, Journal of Aerosol Science, 18 (1), pp. 1-10

Selinus, O., Finkelman, R.B., Centeno, J.A, 2010, Medical Geology: A regional synthesis, springer. pp: 391

Shaw, G. E. 1980. Transport of Asian desert aerosol to the Hawaiian Islands. Journal of Applied Meteorology, 19, 1254-1259.

Sokolik, I.N., Toon, O.B., Bergstrom, R.W., 1998. Modeling the radiative characteristics of airborne mineral aerosols at infraredwavelengths. Journal of Geophysical ResearchAtmospheres 103 (D8), 8813-8826

Sturges, W.T., Harrison, R.M. , Barrie L.A., 1989. Semi-quantitative XRD analysis of size fractionated atmospheric particles, Atmospheric Environment, 23 , 1083-1098

Talbot M.R. and Allen P.A. 1996. Lakes. in Sedimentary Environments: Reading H.G. (ed), Processes, Facies and Stratigraphy, Blackwell: Oxford, 83-124.

Tegen, I., Fung, I., 1994. Modeling of mineral dust in the atmosphere: sources, transport, and optical thickness. J. Geophys. Res. 99, 22897-22914.

Thurston, G.D., Spengler, J.D., 1985, A quantitative assessment of source contributions to inhalable particulate matter pollution in metropolitan Boston. Atmospheric Environment, 19, 9-25. 
Tirrul, R., Bell, I. R., Griftis, R. J., Camp, V. E., 1983. The Sistan suture zone of eastern Iran. Bull. of Geological Soc. of America, 94, 134-150.

Usher,C.R., Michel, A.E., VH Grassian, V.H. 2003. Reactions on mineral dust, Chemical Review, 103 (12) , 4883-4940

Wang, Y., Guoshun, Z., Xingying, Z., Kan, H., Chang, X., Aohan, Jianmin, C. and Zhisheng, A. 2006. The Ion Chemistry, Seasonal Cycle, and Sources of PM2.5 and TSP Aerosol in Shanghai. Atmos. Environ. 40: 2935- 2952

Wang, Y., Zhuang, G., Tang, A., Zhang, W., Sun, Y., Wang, Z., et al. 2007. The evolution of chemical components of aerosols at five monitoring sites of China during dust storms. Atmospheric Environment, 41, 1091-1106. doi:10. 1016/j.atmosenv.2006.09.015.

Wedepohl, K.H., 1971. Environmental influences on the chemical composition of shales and clays. In: Ahrens, L.H., Press, F., Runcorn, S.K., Urey, H.C. (Eds.), Physics and Chemistry of the Earth. Pergamon, Oxford, UK, pp. 307-331

Whitney, J. W., 2006. Geology, Water, and Wind in the Lower Helmand Basin, Southern Afghanistan U.S. Geological Survey, Reston, Virginia, Retrieved 2010-08-31

Wilson, W.E., Chow, J.C. Claiborn, C. Fusheng, W. Engelbrecht, J. and Watson, J.G., 2002, Monitoring of particulate matter outdoors. Chemosphere, 49, 1009-1043

Wood, W. W., \& Sanford, W. E. 1995. Eolian transport, saline lake basins and groundwater solutes. Water Resources Research, 31, 3121-3129.

Xi, X., and Sokolik,I.N 2012 Impact of Asian dust aerosol and surface albedo on photosynthetically active radiation and surface radiative balance in dryland ecosystems. Advances in Meteorology, (in press)

Yang, X.P., Zhu, B.Q., White, P.D. 2007, Provenance of aeolian sediment in the Taklamakan Desert of western China, inferred from REE and major-elemental data. Quaternary International 175, 71-85.

Zarasvandi, A., 2009, Environmental impacts of dust storms in the Khuzestan province, Environmental Protection Agency (EPA) of Khuzestan province, Internal Report, 375p

Zhang, D. D., Peart, M., Jim, C. Y., He, Y. Q., Li, B. S., \& Chen, J. A. 2003. Precipitation chemistry of Lhasa and other remote towns, Tibet. Atmospheric Environment, 37, 231240. 